\title{
Effect of Number of Worker Bees in Queen Mating Nucleus on Queen Quality and Mating Nucleus Population Dynamics
}

\author{
Havva Nur Gülcan ${ }^{1}\left(\mathbb{D}\right.$, Halil Yeninar $^{2, *}\left(\mathbb{D}\right.$, Salim Aktürk ${ }^{3}$ \\ ${ }^{1}$ Kahramanmaraş Sütçü İmam University (K.S.Ü), Graduate School of Natural and Applied Sciences, Kahramanmaraş, \\ Turkey \\ ${ }^{2}$ Kahramanmaraş Sütçü İmam University (K.S.Ü), Faculty of Agriculture, Kahramanmaraş, Turkey \\ ${ }^{3}$ Apiculture Research Institute, Ordu, Turkey
}

\section{Article History}

Received 24 November 2020

Accepted 27 December 2020

First Online 28 December 2020

\section{*Corresponding Author \\ Tel.: +905336549111 \\ E-mail: yeninar@ksu.edu.tr}

\section{Keywords}

Queen rearing

Queen quality

Worker quantity

\begin{abstract}
This study aims to investigate the effects of the amount of worker bees placed into the mating nucleus on queen quality parameters and nucleus population dynamics. The quantity of 80 (g) ( 700 workers) that mating nucleus made of Kirchhain-model can contain has been based on. A total of 24 mating hives, including 8 in each group containing 80, 160 and 320 grams worker bees increasing at a geometric progression, were used in the study. Each mating nuclei been used in queen production for 3 times ( 20 day interval) without any addition of worker bees, depending on the climate and vegetation conditions during the production period. In groups containing 80,160 and 320 gram workerbees, spermatheca diameters $(\mathrm{mm}) 1.14 \pm 0.19,1.11 \pm 0.13$ and $1.16 \pm 0.09$, sperm counts stored in spermatheca $3268859 \pm 288.830,4217444 \pm 182468$ and $4875752 \pm 304443$, live weights of the laying queen $(\mathrm{mg}) 188.5 \pm 2.55,205.8 \pm 4.09$ and $229.6 \pm 4.34$, worker bee weights $(\mathrm{g})$ in mating nuclei after research were $100.85 \pm 4.39,223.85 \pm 14.44$ and $413.66 \pm 43.84$ found to be respectively. At the end of the study conducted in Hatay Province between April 25 - June 25 2019, overall increase in the worker bee population was observed average to be $31.87 \pm 5.39 \%$. The population increase in 80,160 and $320 \mathrm{~g}$ of live worker bee groups were observed to be $26.07 \pm 5.47,39.91 \pm 9.02$ and $29.27 \pm 13.70 \%$ respectively. After 60 days \& 3 periods of queen breeding the differences between groups were found to be statistically insignificant $(P>0.05)$. The differences between the groups, the sperm counts, laying queen weight and amount of worker bees were found to be statistically significant $(P<0.01)$.
\end{abstract}

\section{Introduction}

Beekeeping is an archaic agricultural activity being performed in Anatolia since ancient times. Factors such as topographic and climatic characteristics of Turkey, it's status of natural bridge between Africa, Europe and Asia, the presence of many honey bee races and ecotypes in its fauna, and its rich floristic and faunistic biodiversity have allowed apiculture to be a sustainable agricultural activity in the region for thousands of years.

It has been known that local honey bee ecotypes such as Muğla, Yığılca, Gokceada, etc. are present in Turkey, as well as 5 (A. m. anatoliaca, caucasica, syriaca, carnica and meda) of 26 honey bee races identified in the world. Local honey bee races and ecotypes in Turkey have survived for tens of thousands of years by adapting to biotic and abiotic conditions in their respective regions. Although Turkey possesses great genetic diversity in terms of honey bee race and ecotypes, the apiculture sector could not benefit sufficiently from the genetic diversity Turkey possesses. In addition, breeding methods could not be developed to obtain local races and ecotypes in terms of economically substantial physiological and behavioural traits. Therefore, sustainable pure breeding race, line and commercial use hybrids could not be generated from them. The sector has had to make commercial production due to the presence of unproductive hybrids of races and ecotypes that copulate with each other in an uncontrolled manner as a result of improper queen production, method and policies. Use of them in intra-regional and inter-regional migratory beekeeping practices by marketing local genotypes adapted to certain habitats to eco-geographic regions very different from their 
natural habitats have caused genetic pollution across the country.

Physiological and behavioural traits of honey bee colonies are related to breeding value and quality of the queens used and the genotype and number of drones with which they mate, as well as to beekeeping practices (colony management, feeding, etc.) and their habitat and climate conditions. In the majority of commercial queen-rearing enterprises with a production permit, breeding bee selection is made according to body color, but drone production and breeding have been hardly ever made.

According to the year 2020 data of the Ministry of Agriculture and Forestry, there are 8128360 honey bee colonies in 80675 beekeeping enterprises in Turkey. During the 2019 beekeeping period, 109330 tons honey were produced (Anonymous, 2020a). For sustainable economic beekeeping, it is necessary to change the queens of colonies used in commercial production yearly if possible, otherwise biyearly. Considering the additional queen losses in honey harvest, colony increases and beekeeping practices during the production period, the sector needs at least 4-5 million of pure race/ecotype, breeding and commercial use hybrid quality queens yearly. It is inevitable to experience yield and colony losses in beekeeping practices devoid of a queen replacement system.

Although it varies according to years in Turkey, there are 146 commercial queen production enterprises that can operate with a total production capacity of 510200 / year and have received production permit according to the 2020 data of the Ministry of Agriculture and Forestry. There are 6 breeding and 7 licensed queen production enterprises owned by the public and private sector where the queens can be used for breeding purposes. There is a total of 12 races/ecotypes registered under the names of "Anatolian Ecotype, Central Anatolian Ecotype, Caucasian Ecotype, Thrace Ecotype, Aegean Ecotype, West Aegean Ecotype, R\&D, Ecotype, Giresun Ecotype, Muğla Ecotype, Black Sea Ecotype and Yığılca Ecotype" in these enterprises (Anonymous, 2020b).

Since the shortage of approximately 4 million of queen per year the sector needs cannot be compensated by commercial queen production enterprises, this causes an increase in the rate of old and poor-quality queen use and an increase cannot occur in the desired efficiency. The beekeepers mostly use swarm queens and queen cells in re-queening, colony division and production facilities. The colonies generated by swarm queen and queen cells, bad selection is made that increases the frequency of swarming behaviour in future generations, which in turn causes unwanted physiological and behavioural traits to continue increasingly.

Queens are the most important individuals in terms of their position in the colony. By combining the hereditary traits they get from the drones during the mating flight with their own hereditary characteristics, the queens transfer them to the worker bees with different numbers and degrees of kinship in the superfamily structure that forms the colony. While the drones mating with the queens dies, the sperms of the dying drones can survive for as long as 5 years in the spermatheca of the queen in a mixture with the sperms of other mating drones.

Nuclear colonies queenless in different physical structures and sizes are used in commercial queen production, which are called the mating nucleus, where the queen pupae come out of the cells and perform the first offspring raising activity by mating. During the preparation of the mating nucleus, different numbers of worker bees are placed for the care and feeding of the queens according to their physical characteristics, and the worker bees in each box are used for the mating with more than one queen sequentially during the production season. The number and physiological age composition of worker bees in the mating nucleus vary depending on time. New worker bees, which can be generated from the eggs of young queens, can extend the effective use of mating nucleus during the production season. This study aims to investigate the effects of the amount of worker bees placed in a queen mating nucleus on thequeen quality and mating nucleus population dynamics in the oncoming production process.

\section{Materials and Methods}

The research was carried out in the Eastern Mediterranean coastal zone (Hatay Province), which is one of the locations where seasonal climatic conditions and vegetation become suitable for queen bee breeding at the earliest period in Turkey. The research was realized at $36^{\circ} 19^{\prime} 49.60$ "North latitude, 36¹1'33.29" East longitude an altitude of $145 \mathrm{~m}$ from the sea between 25 April-25 June 2019, at Mustafa Kemal University Agricultural Research and Application Center.

\section{Establishment of Mating Nucleus}

A total of twenty-four mating nuclei were used in this study. Eight nuclei were made high-density polystyrene Kirchhain model and remains sixteen nuclei had 5 standard full depth Langstroth timber-framed wooden mating boxes. The nuclei were filled up with young worker bees by shaking from combs of brood nest taken from Anatolian honey bee (Apis mellifera anatoliaca) colonies two days ago before introducing the queen cells. The shaken young bees were anaesthetized with $\mathrm{CO}_{2}$ and weighted analytical balance with $0.01 \mathrm{mg}$ precision before the installation to nuclei. Nuclei were categorized into three groups contain eight nucleus. Each groups filled with $80 \mathrm{~g}, 160 \mathrm{~g}$ and $320 \mathrm{~g}$ worker bees. 
Table 1. Post-mating average Live Weights $( \pm$ S.E.) $(\mathrm{mg})$ and percent population change of queen breeding in nucleus with different quantity of worker bees.

\begin{tabular}{lcccc}
\hline $\begin{array}{c}\text { Amount of } \\
\text { Worker Bee }(\mathrm{g})\end{array}$ & $\mathrm{n}$ & $\begin{array}{c}\text { Mated } \text { \% Weight }(\mathrm{mg}) \\
(\overline{\mathrm{X}} \pm S \bar{x})\end{array}$ & $\mathrm{n}$ & $\begin{array}{c}\text { Population Increase (\%) } \\
(\overline{\mathrm{X}} \pm S \bar{x})\end{array}$ \\
\hline 80 & 23 & $188.5 \pm 2.55 \mathrm{a}$ & 7 & $26.07 \pm 5.47$ \\
160 & 21 & $205.8 \pm 4.09 \mathrm{~b}$ & 7 & $39.91 \pm 9.02$ \\
320 & 19 & $229.6 \pm 4.34 \mathrm{c}$ & 6 & $29.27 \pm 13.70$ \\
\hline Total & 63 & $206.3 \pm 2.96$ & 20 & $31.87 \pm 5.39$ \\
\hline
\end{tabular}

a,b: Averages with different superscript denoted by small letters in the same column are significantly different $(P<0.01)$. Duncan - Harmonic average sample size $=20.456$

\section{Regulating the Number of Mature Bees In Nuclei}

In production season the anaesthetized with $\mathrm{CO}_{2}$ 50 grams of worker bees were counted and the average adult worker bee weight was calculated as $115 \mathrm{mg}$. The average surface area $\left(\mathrm{cm}^{2}\right)$ of a worker bee on the comb was calculated by measuring the width and length of 100 workers. As a result of the calculation, it has been estimated that the average one worker bee occupies $1.152 \mathrm{~cm}^{2}(1.6 \mathrm{~cm} \times 0.72 \mathrm{~cm})$ areas on the honeycomb surface. The number and weight of adult worker bees were calculated based on the number of bees that could fully cover the total of $800 \mathrm{~cm}^{2}$ honeycomb surface area in the Kirchhain model breeding box. Honeycomb surface area $\left(800 \mathrm{~cm}^{2}\right)$ were divided one worker surface area $\left(1.152 \mathrm{~cm}^{2}\right)$ and found approximately 700 worker bees. Worker number multiplied with average adult worker bee weight (115 mg) approximately equal $80 \mathrm{~g}$ live weight of worker bee. The other two research groups are planned to contain 160 and 320 grams of worker bees, increasing in geometric progression.

Wooden mating nuclei were arranged for one empty honeycomb, one foundation frame and one highdensity polyurethane division board for insulation.

In this study, Anatolian honey bee (Apis mellifera anatoliaca) colonies were used for breeding. One day old larvae were grafted into beeswax queen cell cups by the Doolittle method and were given to starter colonies prepared queenless. In addition to similar applications such as proportional feeding, same colonies were used to eliminate the effects of differences between genotype, starter and finishers.

Mature queen cells were randomly introduced into mating nuclei in the period of ten days after grafting. All queens emerged from the queen cells on the second day after the cells were introduced into the mating nuclei. In order to identify the emergence of queens, mating nuclei were inspected regularly. For the continuity of the mating boxes, the transition of the larvae to the prepupa period (capping brood) was expected. Following, mated queens were collected from nuclei. The mated queens were weighed using an analytical balance with $0.001 \mathrm{mg}$ precision and subjected to dissection to remove spermatheca.
The tracheal net around the spermatheca was cleaned gently and carefully by using fine insect needle and forceps. The diameter of spermathecae was measured under a stereomicroscope equipped with an ocular micrometer. Spermathecae diameters were calculated in two distant points and the average of two measurements were taken. The average radius of each spermatheca was then used to calculate the spherical volume formula: $4 / 3 \pi r^{3}$

The spermathecae were then discharged with a fine forceps in $1 \mathrm{ml}$ of saline solution (0.9\%) in a concave watch glass dish. The final volume was completed by 4 $\mathrm{mL}$ tap water adding to $5 \mathrm{~mL}$. Spermatozoa numbers in spermatheca of the queens were counted five replicates by using a Thoma counting chamber under a light microscope (Mackensen \& Tucker, 1970).

All the virgin queens were mated naturally without drone bee production in research apiary. At the end of queen production season, the workers in nuclei anaesthetized with $\mathrm{CO}_{2}$ were weighted with an analytical balance of $0.01 \mathrm{mg}$ precision. The total live weight change of worker bees between the beginning and the end of the study was determined as weight and percentage.

\section{Statistical Analyses}

Randomized plot design (ANOVA) was used to test the diameter of spermatheca, the number of spermatozoa in the spermathecae, spermatheca volume, live weight change of worker bees and queen weight. Levene's homogeneity test were used for equality of variances. Duncan's Multiple Range Test was used to compare the means between groups. Mating ratios and acceptance rates were analyzed using Chi Square non-parametric tests (Cooley \& Lohnes, 1971). Linear Regression analysis was applied to determine the correlations between dependent and independent variables (Little \& Hills, 1978). Correlation coefficients between all measured character pairs were also calculated. All statistical analyses were performed using SPSS v. 23 for Windows. 


\section{Results}

This research was initiated at the Apiculture and Silkworm Application and Research Center located on the Tayfur Sökmen Campus of Mustafa Kemal University on 25 April 2019. Since abnormal temperature increase is observed depending on global climate changes in June, all of the research materials have relocated to a higher altitude area with dense leaves-shady trees within that region (9-25 June). Only three generations/periods of the queen could be bred in the region during the research lasting for two months.

During the research, absconding behaviour was not observed in any of a total of 2 types-24 mating nucleus containing 80, 160 and 320 grams of live worker bees. Queen was occurred to emerge from all mature queen cell transferred to the mating nucleus in all groups. Two mating nucleuses were omitted from the experiment because wing deformation was observed in queens emerging from the one for each cell in groups containing 160 and 320 grams of worker bees from mature queen cells placed in the mating nucleus by producing from the first group larva transfer.

As wing deformation was observed in one queen that emerged from the cell in the third production in the group containing 80 grams of worker bees, one nucleus from each group (a total of 3 ) was excluded from the experiment throughout the research. Since one queen could not return from its mating flight in the first graft in the group containing 320 grams of worker bees, the relevant nucleus was excluded from the experiment. Therefore, differences appeared in the number of subgroups.

Table 1 presents the post-mating average live weights $(\mathrm{mg}$ ) of the queens being bred in nucleuses containing 80,160 and $320 \mathrm{~g}$ of live worker bees and the percent population changes (\%) in the nucleuses at the end of the experiment. Post-mating live weights of the queen were $188.5 \pm 2.55,205.8 \pm 4.09$ and $229.6 \pm 4.34 \mathrm{mg}$, respectively. The differences between average weights of the queen were statistically significant $(P<0.01, \mathrm{df}: 2$, $\mathrm{F}: 31,261)$ according to the ANOVA test.

The average weight of mated queen in the study groups was calculated as $206.3 \pm 2.96 \mathrm{mg}$. At the end of the research, it was observed that the increase in the amount of worker bees in the nucleus where the queens mate significantly increased the weight of the mated queen.

After 3 periods of queen breeding within 60 days, the average weights of the worker bee in the nucleus containing 80, 160 and 320 grams of worker bees were found to be $100.85 \pm 4.39,223.85 \pm 14.44$ and $413.66 \pm 43.84 \mathrm{~g}$, respectively. When percent weight changes at the end of the research were calculated based on the initial weights, an average population increase was $26.07 \% \pm 5.47,39.91 \% \pm 9.02$ and $29.27 \% \pm 13.70$ respectively, between the groups. Overall, an average population increase of worker bee was $31.87 \% \pm 5.39$ in all groups. Although the highest increase was observed in $160 \mathrm{gr}$ of worker bee group, there were statistically insignificant differences in percent worker bee population between group averages ( $P>0.05$, sd: 2, F: 0.60).

The average diameter of spermatheca $(\mathrm{mm})$ and the number of spermatozoa (piece) determined in queens bred in nucleus containing 80,160 and 320 grams of live worker bees are given in Table 2.

Spermatheca diameters of 80,160 and $320 \mathrm{~g}$ of worker bee groups were $1.14 \pm 0.19,1.11 \pm 0.13$ and $1.16 \pm 0.09 \mathrm{~mm}$, and the differences were statistically insignificant between group averages ( $P>0.05$, sd: $2, F$ : 2.17). The number of spermatozoa stored in spermatheca was $3268859 \pm 288830,4217444 \pm 182468$ and $4875752 \pm 304443$ respectively. The differences were statistically significant between the group averages of the number of spermatozoa stored in the spermatheca ( $P<0.01$, sd: $2, F: 9.383)$. At the end of the research, it has been observed that the population size of the worker bee in the queen bee mating nucleus affected positively the number of spermatozoa stored in the spermatheca.

The differences were statistically insignificant $(P>0.05)$ between the average spermatheca diameters $(\mathrm{mm})$ of the mating queens in the research groups, while the differences were statistically significant between the average values of spermatheca volume $\left(\mathrm{mm}^{3}\right)$ calculated mathematically on the sphere formula $(\mathrm{P}<0.05$, sd: 2, F: 3.417)(Table 3).

At the end of the research, it was found that the queens bred in queen mating nucleus with $320 \mathrm{~g}$ of worker bee population size had the highest and most stable values, with a $0.794 \pm 0.009 \mathrm{~mm}^{3}$ of spermatheca volume value.

\section{Discussion}

A study on "Queen Production Costs and Profitability Analysis in Turkey" by Karaca and Karaman (2018) reported that, during the queen production period, the rate of commercial producers making queen production three times without interruption in a mating nucleus was $75 \%$, the rate of commercial producers making queen production four times was $14 \%$ and the sales period of the first queen started in the second week of April.

Yeninar, Akyol, and Yörük (2007), found that presale live weights of a total of 2.283 mated queens, which they put on the market in plastic queen cages by 7 different commercial queen production firms between April 20 and June 09, 2005, were $189.96 \pm 0.5 \mathrm{mg}$ on average within the range of 174.2 to $207.2 \mathrm{mg}$.

Arslan, Arslan, Cengiz, and Karakuş (2018) found that a total of 105 queen samples raised in 21 commercial producers in the early period in the Mediterranean coastal region had an average of $191.04 \pm 2.094 \mathrm{mg}$ live weight $( \pm \mathrm{SE})$, had an average of 
Table 2. Average spermatheca diameter $( \pm$ S.E.) $(\mathrm{mm})$ and spermatozoa number (pieces) of queen breeding in nucleus with different quantity of worker bees.

\begin{tabular}{cccc}
\hline $\begin{array}{c}\text { Amount of Worker } \\
\text { Bee }(\mathrm{g})\end{array}$ & $\mathrm{n}$ & $\begin{array}{c}\text { Spermatheca Diameter }(\mathrm{mm}) \\
(\overline{\mathrm{X}} \pm S \bar{x})\end{array}$ & $\begin{array}{c}\text { Spermatozoa Number (pieces) } \\
(\overline{\mathrm{X}} \pm S \bar{x})\end{array}$ \\
\hline 80 & 23 & $1.143 \pm 0.19$ & $26.07 \pm 5.47$ \\
160 & 21 & $1.116 \pm 0.13$ & $39.91 \pm 9.02$ \\
320 & 19 & $1.163 \pm 0.09$ & $29.27 \pm 13.70$ \\
\hline Total & 63 & $1.140 \pm 0.09$ & $31.87 \pm 5.39$
\end{tabular}

a,b: Averages with different superscript denoted by small letters in the same column are significantly different $(P<0.01)$.

Duncan - Harmonic average sample size $=20.456$

Table 3. Post-mating calculated spermatheca volume $\left(\mathrm{mm}^{3}\right)$ of queen breeding in nucleus with different quantity of worker bees.

\begin{tabular}{ccccc}
\hline $\begin{array}{c}\text { Amount of Worker Bee } \\
(\mathrm{g})\end{array}$ & $\mathrm{n}$ & $\begin{array}{c}\text { Spermatheca Volume }\left(\mathrm{mm}^{3}\right) \\
(\overline{\mathrm{X}} \pm S \bar{x})\end{array}$ & Minimum & Maximum \\
\hline 80 & 23 & $0.742 \pm 0.026^{\mathrm{ab}}$ & 0.51 & 0.98 \\
160 & 21 & $0.726 \pm 0.116^{\mathrm{a}}$ & 0.63 & 0.84 \\
320 & 18 & $0.794 \pm 0.009^{\mathrm{b}}$ & 0.74 & 0.88 \\
\hline Total & 62 & $0.752 \pm 0.011$ & &
\end{tabular}

a,b: Averages with different superscript denoted by small letters in the same column are significantly different $(P<0.05)$.

Duncan - Harmonic average sample size $=20.456$

$1.044 \pm 0.071 \mathrm{~mm}$ spermatheca diameter, had an average of $0.605 \pm 0.012 \mathrm{~mm}^{3}$ spermatheca volume and had $4.454 \pm 0.177$ million spermatozoa.

In a study carried out in Hatay, Uzun (2020) reported that post-mating live weight of the queen was $186.76 \pm 2.87 \mathrm{mg}$, the spermatheca diameter was $1.18 \pm 1.09 \mathrm{~mm}$, the spermatheca volume was $0.87 \pm 0.02$ $\mathrm{mm}^{3}$, and the number of spermatozoa present in the spermatheca was $4655369 \pm 428171$ per queen.

The data from this study are consistent with the quality parameters from commercial and research queen produced at equivalent queen production dates in different years in the Mediterranean coastal zone.

\section{Conclusion}

The first queen production of the year in Turkey has being made in the Mediterranean coastal region where climate and habitat are the most suitable. Many producers engaged in migratory professional beekeeping activities also prefer the same region for overwintering. Demand for the massive queen after overwintering in the region is seen in April and May, the months of which coincide with the natural swarming season when pollen and nectar sources are most abundant in the relevant region. The climate and habitat characteristics of that region have a stimulating effect on quality queen production. Due to the reasons mentioned above, almost all of the commercial queen producers overwinter in the Mediterranean coastal region and market their first productions to beekeepers before the highland honey production period.

Intensive intra- and interzonal migratory beekeeping activities in Turkey cause queens to rapidly burn out and age in physiological terms. Due to old and physiologically burnt-out queen colonies, the colony population cannot reach a sufficient level during the production season, and significant winter losses are experienced depending on the negative effects of global climate changes.

An average of $40 \mathrm{mg}$ live weight increase $(229.6 \pm 4.34 \mathrm{mg})$ was observed in a statistically significant manner $(P<0.01)$ between queens raised in Kischain model-nucleus with $80 \mathrm{~g}$ of worker bees and those raised in standard Langstroth framed-nucleus with $320 \mathrm{~g}$ of worker bees. Overall, the live weight of young queens used in production should be $200 \mathrm{mg}$ and above (Akyol, Yeninar \& Kaftanoglu, 2008) since this is 
considered a quality criterion. Population development, acceptance rate of young queens and production efficiency are higher in colonies of queen with a great live weight. Similarly, an increase of spermatozoa was detected in a statistically significant manner $(P<0.01)$ by an approximate rate of $50 \%$ in the spermatheca of queens. These results affect positively the effective use of queen in production during commercial beekeeping activities. In addition, they can be used easily in production and adult bee trade with standard beekeeping materials by renewing worker bees in standard Langstroth framed-nucleus after the queen production period. Therefore, sustainable production can be achieved. Addressing this current issue economically in other researches would contribute to the apiculture sector.

\section{References}

Anonymous, (2020a). Arıcılık istatistikleri. Retrieved fromhttps://arastirma.tarimorman.gov.tr/aricilik/Link/2 /Aricilik-Istatistikleri. Turkey Apiculture Statistics for Production of Honey in 2019.

Anonymous, (2020b). Retrieved from https://www.tarimorman.gov.tr/HAYGEM/Belgeler/Hay vancılık/Küçük Evcil Yetiştiriciliği/Arıcılık/2020 YILI/Ana Arı Üretim İzinli İşletmeler.xls
Akyol, E., Yeninar, H., \& Kaftanoglu, O. (2008). Live weight of queen honey bees (Apis mellifera L.) predicts reproductive characteristics. Journal of the Kansas Entomological Society, 81(2), 92-100.

Arslan, S., Arslan, H.S., Cengiz, M.M., \& Karakuş, B. (2018). Determination of conformity of the quality criteria to queen production standards in the early period of Mediterranean Region. $6^{\text {th }}$ International Mugla Beekeeping \& Pine Honey Congress (pp.42-48). Muğla, Turkey.

Colley, W.W., \& Lohnes, P.R. (1971). Multivariate Data Analysis. Multivariate Data Analysis, John Wiley \& Sons. New York, 364 pp.

Karaca, Ü., \& Karaman, S. (2018). Queen Production Costs and Profitability Analysis in Turkey. Anadolu Journal of Aegean Agricultural Research, 28(2), 17-28.

Little, T. M., \& Hills, F. J. (1978). Agricultural Experimentation. John Wiley \& Sons. New York, 350 pp.

Mackensen, O., \& Tucker, K.W. (1970). Instrumental insemination of queen bees. Agriculture Handbook, No:390; Washington. pp. 1-28.

Uzun, M.Y. (2020). The Effect of Different Feeding Diets on Queen Bee Quality Parameters (MSc Thesis). Mustafa Kemal University, Hatay, Turkey.

Yeninar, H., Akyol, E., \& Yörük, A. (2007). Investigation of body weight changes in mated queens produced in queen bee-producing companies. III. Marmara Beekeeping Congress (pp.25). Bursa, Turkey. 